\title{
Social representations of HIV/AIDS among seropositive pregnant women*
}

\author{
Representações sociais do HIV/AIDS entre gestantes soropositivas \\ Representaciones sociales del VIH/SIDA entre mujeres embarazadas seropositivas
}

How to cite this article:

Freire DA, Oliveira TS, Cabral JR, Angelim RCM, Oliveira DC, Abrão FMS. Social representations of HIV/AIDS among seropositive pregnant women. Rev Esc Enferm USP. 2021;55:e20200192. DOI: https://doi.org/10.1590/1980-220X-REEUSP-2020-0192

(D) Daniela de Aquino Freire ${ }^{1}$
(iD) Thais da Silva Oliveira ${ }^{1}$
(iD) Juliana da Rocha Cabral ${ }^{1}$
(D) Rebeca Coelho de Moura Angelim ${ }^{1}$
(iD) Denize Cristina de Oliveira ${ }^{2}$
(D) Fátima Maria da Silva Abrão ${ }^{1}$

* Extracted from the dissertation "O enfrentamento da soropositividade por gestantes: um estudo de representações sociais", Programa de Pós-Graduação em Enfermagem, Universidade de Pernambuco/Universidade Estadual da Paraíba, 2018.

${ }^{1}$ Universidade de Pernambuco, Programa Associado de Pós-Graduação em Enfermagem, Recife, PE, Brazil

${ }^{2}$ Universidade do Estado do Rio de Janeiro, Programa de Pós-Graduação em Enfermagem, Rio de Janeiro, RJ, Brazil.

\begin{abstract}
Objective: To identify the representational contents of pregnant women living with HIV. Method: Exploratory, descriptive, qualitative study, conducted with pregnant women with HIV from August 2017 to January 2018. Semi-structured interview was opted for. The IRAMUTEQ software was used for analysis, organizing the data into 2 blocks: a) moment of discovery, impacts, representational contents of HIV; and b) representational contents in living with the disease. Results: The participating pregnant women amounted to 25. Initially, the social representation of HIV translated the representation of death; however, this construction changes as women understand information of the pathology, which starts to be seen as a disease which demands more care. Conclusion: The conception of HIV as frightful is mainly due to concern about transmission to the fetus. The resignification of HIV was perceived among pregnant women, which favors new behaviors and attitudes towards the representational contents related to a deeper knowledge about the virus, demystifying the idea that this is a deadly disease.
\end{abstract}

\section{DESCRIPTORS}

Pregnant Women; HIV; Acquired Immunodeficiency Syndrome; Social Perception; Obstetric Nursing. 


\section{INTRODUCTION}

Throughout four decades, growth and significant changes in the global context of infection by the human immunodeficiency virus (HIV) were observed. This context represents important epidemiological transformations, which are marked by the phenomena of feminization (women in reproductive age), juvenilization, its spread in inland areas, and pauperization ${ }^{(1-2)}$. Thus, in Brazil, around 125 thousand pregnant women lived with HIV from 2000 to 2019 . This rate has been presenting a considerable increase in the last 10 years $^{(3)}$.

Most women find out their serologic condition only when they know that their child was infected (in prenatal, delivery, or puerperium). However, in recent years, a noteworthy increase in this type of diagnosis was observed; this was due to the increase of screening with rapid tests throughout the pregnancy ${ }^{(4)}$.

For the pregnant women, recognizing their positive serology for HIV represents changes to the value attributed to their own life, as well as of the fetus in their wombs, with repercussions for interpersonal relations, given the stigmas and stereotypes around HIV since the emergence of the epidemics. Also, many pregnant women with HIV are afraid to face society due to prejudice and stigma still present in current days. Due to all these factors, pregnant women are vulnerable to a number of problems - particularly psychological issues ${ }^{(5-6)}$.

Thus, in order to establish care directed at needs of pregnant women with HIV, understanding the individual psychosocial aspects of these women is crucial. In this sense, investigating the process of construction of social representations of HIV within their historical, social, and cultural context becomes indispensable. To understand the challenges and the reality of pregnant women with HIV, studies abiding by the Social Representation Theory (SRT) is necessary, since this is anchored on the sociopsychological current named social thinking ${ }^{(7)}$.

The SRT is defined by socio-affective and mental elements, integrating them to cognition, language, and communication while contributing to the construction of collective identities ${ }^{(8)}$. Therefore, studies based on SRT are important in contexts involving pregnant women with HIV, given that this enables the comprehension of the construction of phenomena through the meanings attributed by subjects to their actions based on their contexts of occurrence ${ }^{(9)}$.

Also, representation must be understood as the outcome of interaction and communication since it provides a broad understanding of social phenomena and their psychosocial influences on society ${ }^{(10)}$.

Thus, it is necessary to understand how the social group of pregnant women with HIV understand the representational contents of HIV/AIDS, as well as their repercussion in daily life, given that their influence may entail the aggravation of the health status and well-being of this population. The analysis of social representations in pregnant women with HIV may reflect on what can be improved in provided care, particularly by nurses. Therefore, it is aimed at improving care provided to these clients, given the context of stimulation to medication adherence, reduction in stigma, and self-care.

Given this comprehension, subjects are corroborated to express themselves through social representations while constructing themselves socially. This study aimed thus at identifying the representational contents of pregnant women with HIV facing the infection.

\section{METHOD}

\section{Design of Study}

This is a descriptive, qualitative study based on SRT proposed by Serge Moscovici ${ }^{(10)}$ - using the processual approach, which brings social representation as a manner of comprehension created and shared within society, favoring the creation of a reality in a social group ${ }^{(8)}$.

\section{Population}

This study was performed in a specialized care service (SCS) of HIV located in Recife, Pernambuco state, Brazil, from August 2017 to January 2018. The long period of collection is justified by the fact that this occurred only twice a week (on Mondays and Thursdays), abiding by the authorization of this SCS.

The choice of HIV SCS is justified by the fact that it provided integral care to pregnant women living with HIV through actions of care, prevention, and treatment with a multiprofessional team, in addition to providing access via the Unified Health System (Sistema Único de Saúde - SUS). The study participants were pregnant women undergoing therapeutic follow-up in the study SCS. According to the register of the local data collection management team, in the study period, the SCS presented a monthly mean of 42 consultations of pregnant women with HIV.

The inclusion criteria for this study were: a) pregnant women over eighteen years old; b) pregnant women with an HIV diagnosis for at least 6 months; and c) pregnant women undergoing outpatient follow-up in the HIV SCS. The exclusion criteria were a) pregnant women who had no ability of discerning and understanding; and b) pregnant women with a history of mental conditions described in the medical records.

\section{SAMPLE}

The process of data collection was finished after a sample of 25 pregnant women was achieved. To this end, the criterion of report saturation was adopted, given the repetition of representational contents of the studied social object.

\section{Data Collection}

A semi-structured questionnaire was used for sociodemographic and clinical characterization of participants, approaching variables such as age, education, religion, number of pregnancies, number of children alive, child's serology, income, head of household, route of contamination 
for HIV, time from diagnosis, and use of antiretroviral therapy. A semi-structured interview was also conducted to apprehend the moment of discovery, the impacts, and the representational contents of HIV.

The participants were interviewed individually in a private room in the HIV SCS. A digital device was used to record all interviews. With a mean duration of one hour, these interviews were conducted in a calm environment, with no interruptions. They have been thoroughly transcribed.

Subsequently, the following steps were implemented: a) all reports were completely registered in the Microsoft Word software; b) the texts were submitted to orthographic correction; and, finally, c) the content was grouped in a text corpus, generating a single text file in the OpenOffice software. The identity of all participants was preserved by codifying their names through the abbreviation GEST ("Gestation"), the sequential interview, number and the age range (e.g., GEST 01, 18 to 23 years).

\section{Data Analysis and Treatment}

For treatment of clinical and socioeconomic data, the absolute frequencies in the spreadsheet of software Epi Info, version 3.5.2., have been used. The textual corpus, composed of the interviews, was organized in a document of the Microsoft Word software and transferred to Notepad, aiming at a subsequent analysis. The IRAMUTEQ software (Interface de $R$ pour les Analyses Multidimensiononnelles de Textes et de Questionnaires) has enabled the analysis of the textual corpus through descending hierarchical classification (DHC).

The DHC enabled an analysis of each text, divided into segments. Thus, lexical classes have been built according to the vocabulary. For this study, contents of 6 classes of representational phenomena of pregnant women living with $\mathrm{HIV}$, in addition to discovery and impact of diagnosis, were analyzed and discussed.

\section{Ethical Aspects}

This study abided by Resolution n. 466/2012 and Resolution n. 510/2016, by the National Health Council, and was approved by the Research Ethics Committee of Universidade de Pernambuco in Opinion n. 2.009.411, dated 2017. All participants have signed the Informed Consent Form (ICF).

\section{RESULTS}

Concerning sociodemographic data, among the 25 study participants, 5 pregnant women were in the age group from 18 to 23 years old, 8 were 24 to 29 , other 8 were 30 to 35 , and 4 were 36 to 40 . In relation to marital status, 14 were single. Regarding education and religion, respectively, 12 had finished secondary education and 13 reported following evangelical doctrines. Low income was predominant - 11 pregnant women reported having a monthly income under one minimum wage (a mean of 800.00 Brazilian Reais) - and 15 were not centrally responsible for this income.
Regarding the number of pregnancies, 8 participants were in their first one, 6 in the second, 4 in the third, and 6 in the fourth pregnancy; 16 participants said they had at least 1 child and among these 4 had 1 child with HIV diagnosis. In addition, 19 pregnant women reported that HIV infection was through sexual relation and 6 did not know; 12 women had a recent diagnosis, in the start of the current pregnancy, at least 7 months prior. Concerning the treatment with antiretroviral therapy, 22 pregnant women reported having started treatment after finding out the pregnancy.

It is important to emphasize that the vocabulary used to build the dendrogram and describe each class was determined by the number of text segments containing the word in the class, by association between word and class and the level of importance of the relation with the class. In this manner, the following categories were elaborated: a) "The moment of discovery, the impacts and their representational contents"; and b) "The representational contents in living with the disease" (Figure 1).

To facilitate the comprehension of social representations, the results have been divided into the categories presented below.

\section{Category 1: The Moment of Discovery, The Impacts, AND THEIR RepresentatIONAl CONTENTS}

According to the segments, the discovery of diagnosis was found to have happened in different moments, occurring during prenatal or in routine exams, according to the utterances below:

I found out when the doctor prescribed the regular routine exa$m s$, the HIV exam, syphilis, and I had them done (GEST 06, 30 to 35 years old).

I found out after I knew I was pregnant; I had the exams done, and they pointed out HIV (GEST 16, 30 to 35 years old).

When I was pregnant and got my exams done, the HIV exam was positive during prenatal (GEST 23, 18 to 23 years old).

The participants were also observed to find out their diagnosis after their partner tested positive:

My husband was hospitalized, he got very thin; he showed me the paper, I couldn't believe it. So I got mine and my other boy's done; mine was reactive (GEST 07, 24 to 29 years old).

I found out through my husband. The doctor said that he had it and I was infected. I was examined and the result was positive (GEST 09, 36 to 40 years old).

A negative impact is identified upon receiving the HIV diagnosis. The reports indicate that some pregnant women compared HIV to death, a perception which may derive from the growing number of deaths related to this virus during its epidemic, given that HIV first emerged as a deadly disease. This perception is confirmed by the following reports:

Girl, that was the worst news I ever received in my whole life. I left the hospital in tears, it was horrible, horrible, horrible, borrible. HIV is death. That was the worst news I ever received in my whole life (GEST 01, 18 to 23 years old). 
Representational contents of HIV/aids in pregnant women with HIV

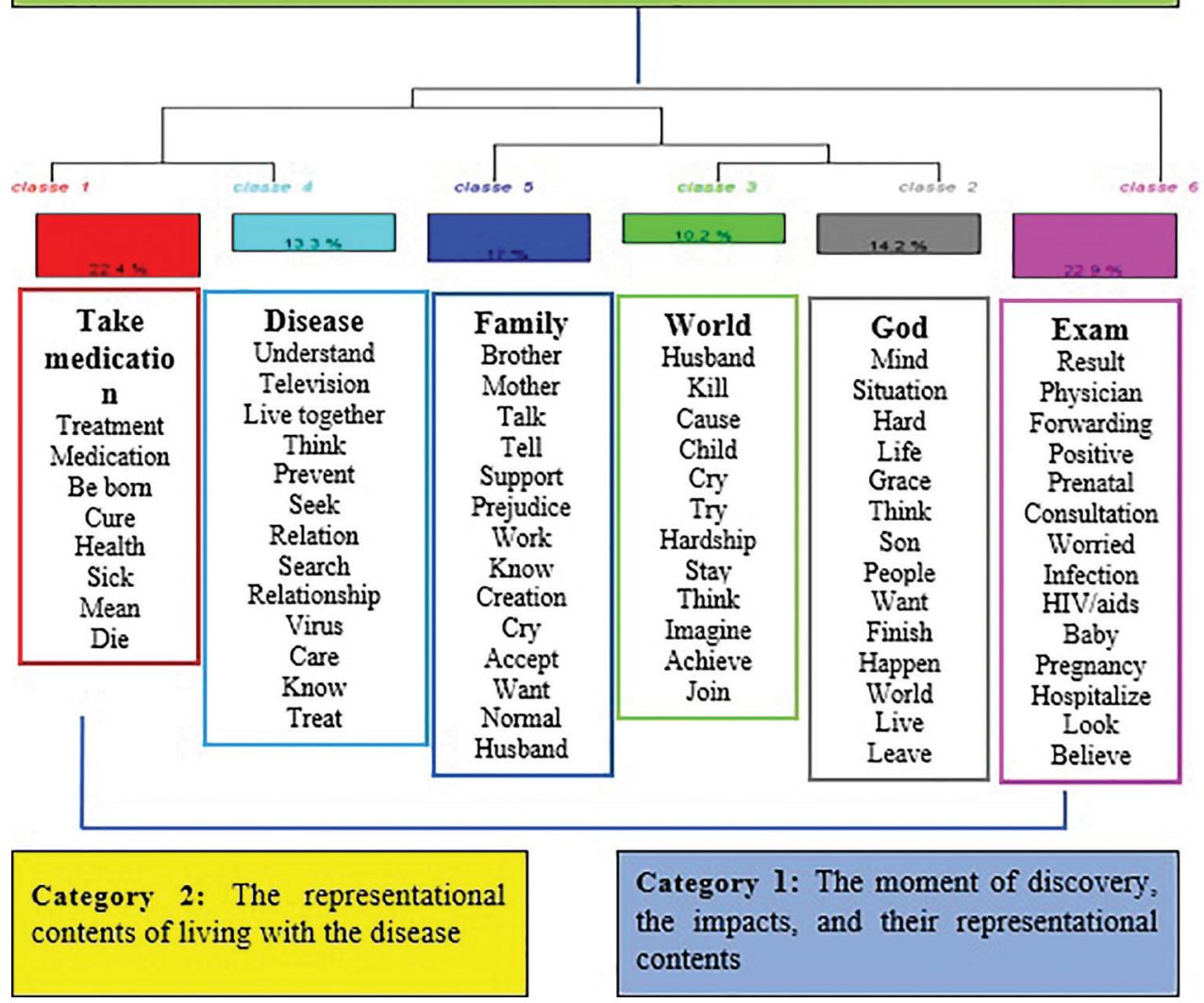

Figure 1 - Distribution of classes per vocabulary.

That moment meant death. I was in despair, I cried a lot, thinking what I should do with my life (GEST 03, 30 to 35 years old).

It was very sad, I thought I'd die soon, that was certain death for me (GEST 09, 36 to 40 years old).

There were also those who were shocked, as well as others who thought about the health of the fetus after diagnosis:

When he said he was sure I had HIV, I still cried a little more, outside. I was a little nervous, but all because of the child (GEST 04, 36 to 40 years old).

I cried an awful lot. I didn't want to believe. I thought I'd got it wrong, but deep down you know; it was reactive, there's no other possibility (GEST 16, 30 to 35 years old).

The fear of infecting their child with the virus leads to a stressful situation; feelings of hope or guilty conscience are perceived likewise. These feelings may be associated to the social representation of a deadly disease:

I was scared because of the child; I would pray saying "the child won't have it", I am sure of this (GEST 04, 36 to 40 years old).

I thought about my baby, you know? I asked the doctors if this would infect the baby and they said it could happen, but if
I took my medicine properly it wouldn't (GEST 12, 18 to 23 years old).

Today the biggest exclusive dedication is to my daughter's birth; I very often find myself hoping for a calm delivery, a delivery in which I don't pass it to my daughter (GEST 13, 36 to 40 years old).

In addition, these women are faced with prejudice from others, attitudes which may be anchored on the disease due to the earliest events of the epidemics, and this entails psychic suffering:

People have prejudice. They have prejudice against people with $H I V$. It's as if the disease was something I can't even explain (GEST 15, 30 to 35 years old).

This is very complicated to live with. It's an enormous suffering because people's prejudice is huge. You walk by and people talk about people with HIV and this is embarrassing (GEST 16, 30 to 35 years old).

Representational contents of fear, distress, death, and helplessness can be initially perceived among the pregnant women.

\section{Category 2: The Representational Contents of LiVING WITH THE DiseASE}

In Block 2, which deals mainly with representational contents in living with the disease, the pregnant women 
living with the disease are observed to see HIV as divine retribution. This representational content is evident in the following text segment:

It's not good, but I'm psychologically well, I'm cool. I got it because I was supposed to, I screwed up. I'm very clingy to God, I guess this was a punishment (GEST 04, 36 to 40 years old).

The search for information about HIV on the media, the internet, social media, and support networks by some participants was also observed; these may favor resignification:

When I found out, I read on the internet that this was a virus that destroys people's lives because you won't be the same anymore whether you like it or not (GEST 02, 24 to 29 years old).

I understood that this is a virus that is in your blood. And then I looked for information (...) on television and on the internet there's always something about this. I listen and I just keep thinking (GEST 06, 30 to 35 years old).

I believe this is a disease. I see personal accounts on the internet (GEST 12, 18 to 23 years old).

We try to keep informed, understand, and even where we live, people are always well-informed (GEST 13, 36 to 40 years old).

Some women stopped leaving their houses due to being ashamed of themselves. Society's prejudice against people with HIV is noted to favor the isolation of these individuals, who try not to be victimized by it. Thus, the representational content of HIV is seen as the end of life:

You don't want to go out anymore, you start to think you'll have no life anymore, that no one will want to be with you (GEST 16,30 to 35 years old).

Representational contents of HIV regarding "seeing oneself differently" and "suffering/shame" were also identified:

This is a tremendous shock for anyone. This isn't something you'd wish for your worst enemy (...) I see myself differently (GEST 12,18 to 23 years old).

Living with this is very complicated. It's an enormous suffering because people's prejudice is huge. You walk by and people say you have AIDS and this is embarrassing (GEST 16, 30 to 35 years old).

On the other hand, living with the diagnosis is observed to have made the pregnant women to possibly change their representation of HIV, relating the virus with the image of a disease which demands care:

Now I understand that this is not the end of the world, because if we take care and treat it, it takes much longer than cancer or any other disease. So, I feel as if it's diabetes or any other disease (GEST 06, 30 to 35 years old).

There are many people with worse diseases, such as cancer, which has no cure. I fear because we don't die of HIV but because of the diseases. I think about this, I'm afraid of dying of other diseases such as cancer or tumor, something like that (GEST 07, 24 to 29 years old).
If you don't take care, there's more, there's the disease, AIDS. $H I V$ is a disease like any other (GEST 15, 35 to 40 years old).

In some reports, prejudice against oneself is identified. There are pregnant women who, despite the diverse sources of information which may favor the process of resignification, consider HIV as abhorrent, disgusting:

It's the word HIV, just that. What I mean is that this is a much more disgusting disease because it's in your blood (GEST 18, 18 to 24 years old).

I'll always see HIV as death. So, this is why I talk so much about it (GEST 22, 18 to 24 years old).

$H I V$ is a communicable, incurable disease. I'm disgusted at myself(GEST 15, 30 to 35 years old).

Even though many pregnant women presented negative representational contents on HIV, a pregnant woman who can see the positive side of HIV was identified. According to her, the virus was represented as a form of new beginning and transformation of the phenomenon:

But I had to accept HIV. For many people this means the end of everything, but for me, this now means a new beginning in lots of things (GEST 19, 24 to 29 years old).

Also, performing medication treatment is important, since it precludes the emerge of complications related to HIV transmission. In the segments, representational contents aimed at life renewal, a new opportunity, are identified.

I see that treatment is important. If I follow it correctly, take the medicine at the right time, me and my daughter are going to be well to face it (GEST 02, 24 to 29 years old).

Treatment means life renewal (GEST 02, 30 to 35 years old).

Anchoring on their children is noticed to give pregnant women strength to follow the therapeutic conduct for HIV. For them, performing the treatment means having longevity to be able to enjoy moments with their children and to prevent their infection with the viral strand - they are given priority, which favors the representational transformation of a disease initially seen as deadly:

God was good to me for not contaminating my children (GEST 07,24 to 29 years old).

I'm taking care and it won't harm my son. Hopefully he'll be born in good condition, in good health (GEST 08, 24 to 29 years old).

I plan to live well and healthy so I won't pass this virus to my baby; I see her as a good thing in my life (GEST 11, 18 to 23 years old).

I want to go through the treatment. I want to see my son, I've never had a son and I want to see my son (GEST 03, 30 to 35 years old).

Every day I take my medicine before I go to sleep. I can't think only of myself; there's a little baby within me also, so I have to take care of him (GEST 10, 30 to 35 years old). 
With the treatment I see myself, in the future, with my son (GEST 19, 24 to 29 years old).

Living with HIV in the context of pregnancy acquires a new meaning because it occurs due to preservation of the offspring's health. There is no more concern with death, the perception of the disease as the end. The patients started to create different representational contents, associating the need for treatment to their children's life conditions.

Treatment with antiretroviral therapy does not mean cure, but, for some, it represents not dying due to diseases from the immune system deficiency after contamination by the virus. This new view represents the comprehension of the patients regarding the knowledge to differentiate HIV from AIDS:

In my head I understand that I can die at any moment and if I don't take the right medication, I may get sick (GEST 07, 24 to 29 years old).

I see hope in what just a moment ago was a synonym of hopelessness, death, condemnation and now is no longer. I see as if it's a normal treatment, like any other pathology, and I have a great expectation (GEST 13, 36 to 40 years old).

In the previous utterance, the social representation of HIV is clearly perceived as a chronic disease which does not present further risk of death. Concerning representational contents, pregnant women are perceived to start to see the infection as a disease which demands serious treatment, but do not treat it as the end, as death.

In addition, "the fear of prejudice" from acquaintances constitutes a representational content, representation which is anchored on the shame of having HIV or AIDS, a disease of people who are stigmatized by society, and this leads the pregnant women to isolation and avoiding sharing their reality to avoid further suffering:

I'm not worried about the disease itself. It's the prejudice from society, and from my family, also. The only ones who know are my husband and my mother, and no one else (GEST 19, 24 to 29 years old).

(...) I didn't want many people to know because my mother and father are going to think that I'm going to die soon (GEST 04, 36 to 40 years old).

My friends don't know, they don't. I've stopped going out, I carried on with my life, but a little isolated (GEST 16, 30 to 35 years old).

I wish I could be more transparent. I wish I could talk about this and reduce prejudice little by little, but I know my family is not educated enough to accept this well enough (GEST 13, 36 to 40 years old).

I still get frightened. I never mention I have it because I'm afraid of people's prejudice (GEST 08, 24 to 29 years old).

\section{DISCUSSION}

This research has apprehended the concepts and feelings of seropositive pregnant women faced with their serological reality. In this way, the negative impact of finding out HIV may be related to the social representation of HIV as a dangerous disease associated to death, mainly due to their pregnancy. In addition, feelings of shame and prejudice from other people have been identified. This association may be related to a representation from the early epidemics which is still present in society.

It must be emphasized that testing positive for HIV brings negative attitudes, which are expected at that moment, considering that, even with advancements in treatment with antiretrovirals, there is still no cure. In addition, an adaptation to a new world, full of uncertainties and, consequently, insecurity, is required. A study with pregnant women in search of rapid test for HIV has shown "fear", "death", "suffering", and "prejudice" to be the main representational contents of $\mathrm{HIV}^{(11)}$. These feelings may favor these women's solitude, compromising their quality of life.

Representational contents of HIV among pregnant women upon receiving the diagnosis are presented in this study; these are characterized by proximity of death, such as fear, sadness, distress, guilt, HIV as punishment, end of life, sensation of death, fatal disease, disgusting disease, dangerous disease, incurable disease, suffering, insecurity, and suicidal thoughts. The construction of this social representation is anchored on their views of this as a profane disease, associated to sinners, homosexuals, prostitutes, and drug users. The positive diagnosis brings many pre-judgments. These social representations are understood as authentic common-sense theories which are collectively conceived in social contact from person to person and from person to object, in a singular time interval, culture, and environment, with the intention of making strangeness familiar and explain reality ${ }^{(11)}$.

Although this is a different century, in which scientific knowledge of HIV is well-expressed in society, these past stigmas are perpetuated and corroborate the construction of a representation which is stuck in the past. This presupposition is confirmed by observing that some pregnant women consider their HIV status a "punishment", a "guilt", by calling it a "disgusting disease". For these identifications, according to Moscovici ${ }^{(10)}$, anchoring means to transform something strange, disturbing, or intriguing into a particular system of categories and thus is compared to the paradigm of one category which the individual believes to be appropriate. From the moment a certain object is compared to the paradigm of a category, characteristics of this category are created and the object is then readapted to suit that category - anchoring means classifying and naming something ${ }^{(10)}$.

These constructions are emphasized to be possibly formed from information about the disease from the media, which is very influential in the process of dissemination. It is important to report how science increasingly has the media as one of the main departments which initiate and disseminate social representations of many objects of social problems and that these favor the people's everyday life practices. Thus, social representations can be said to be present in social thinking, as well as in $\operatorname{media}^{(12)}$. 
Social representation is "a socially-constructed and shared form of knowledge, having a practical orientation and corroborating for the construction of a common reality for a social set”(12). In addition, social representations are considered to establish a connection between common sense knowledge and reified knowledge, since they constitute a system of receiving information which encircle the social environment, crystalized by situations and experiences of the involved social groups and the present communication processes. Given that, there is a great load of emotion, which favors the dialogues and sharing among people, groups, and societies ${ }^{(12)}$.

A study conducted with people with HIV has presented contents such as: (...) sadness, AIDS as a chronic disease, despair after the diagnosis, fear of AIDS, AIDS as an issue, AIDS as a limiting factor, AIDS as harmful, surprise at the diagnosis, sexually transmitted disease, AIDS as a synonym of pain, disease related to gay people, disease of other people, exclusion by others, outrage at the disease, and disease of the century, evidencing the feeling of sadness with more representativeness ${ }^{(13)}$.

Concomitantly, studies show the centrality of fear in the social representation of AIDS ${ }^{(14-15)}$. This may be associated to the expression "epidemics of fear", showed by the discovery of HIV in the 1980's. This fact imprinted the disease with a representation of fear to individuals living with HIV. The social stigma attributed to HIV was represented by prejudice and discrimination, by fear of being infected with the virus and of death. Fear is a natural and human reaction which may awake and favor alertness to a situation of danger, as shown in the study. In the context of HIV, fear (re)signifies a negative attitudinal connotation, since it derives from a social representation of the start of the HIV epidemics, still present today ${ }^{(15)}$.

Consequently, as time goes by, pregnant women are noticed to incorporate feelings of safety, knowledge targeted at forms of contamination and behavior for prevention and care of oneself and others. A study has shown that stigma, in the first moment of the diagnosis, is the most difficult part, but its reduction takes place through knowledge acquired upon living with positive serology, as it is known that, initially, when patients are diagnosed, they know little about the disease. Developing a comprehension of what it means to live with HIV is fundamental to reduce the stigma ${ }^{(16)}$.

Thus, a comparative study of representations of HIV in different historical periods indicates that, in the period from 1990 to early 2000, a change in the representation of AIDS was observed, in addition to measures for confronting the disease. In the second half of the 2000's and in early 2010, the analysis points to a representation characterized by the construction of "AIDS as a chronic disease", corroborating the results of this study ${ }^{(17)}$.

In this context, it is important to mention that, although the HIV prognosis has changed in the last decades, with a significant reduction in mortality, dissemination of information and evolution of the therapeutic plan, the disease started to be classified as a chronic clinical problem ${ }^{(18)}$.
Changes are necessary for these women, since living with seropositivity and the pregnancy is a moment of intimate rearrangement and they must recognize themselves as mothers and seropositive simultaneously. Thus, they are disseminators of life and of limitations to life ${ }^{(19)}$. It should be emphasized that, while living with a positive HIV diagnosis during a pregnancy, this serologic condition is observed not to reduce the positive feelings related to the pregnancy and the child, but entails uncertainty, fear, and the need for care so as to prevent vertical transmission ${ }^{(20)}$. The social representations are characterized not only as a way of understanding a particular object, but also as a form by which the individual acquires the capacity of definition, an identity, which is one of the manners through which representations express symbolic value ${ }^{(10)}$.

Considering the TSR, the transformations experienced by women with HIV during their pregnancy are perceived, encompassing fear, implying the emergence of various feelings which cause an internal conflict in women. In addition, there is frustration, guilt, sadness, uncertainty, apprehension, and distress. Some of these feelings are related to social representations of HIV for part of society ${ }^{(21)}$.

Given these reflections, it is necessary to improve the offer of care directed to pregnant women with HIV. It is necessary to improve access to knowledge of this disease, demystifying prejudice, promoting changes in discriminating behavior and encouraging the adoption of postures for health protection, not only for physical health, but also psychological ${ }^{(15)}$.

A limitation of this study is pointed to be the fact that this study was conducted in a single health service, investigating the phenomenon from a restricted population.

\section{CONCLUSION}

Exploring social representations of HIV during discovery, the impact, and their representational contents in living with the disease emerge in feelings of fear, distress, death, and helplessness. To this day HIV is still conceived as frightening, mainly due to worries of transmitting it to the fetus.

It is emphasized that, in the process of construction of the identified representations, the specialized care service takes an important role in understanding the disease and confronting it. The resignification of HIV was identified for pregnant women, favoring new behaviors and attitudes, mainly due to their pregnancy, when noticing representational contents related to a deeper knowledge of the virus, which refer to the possibility of appropriate care, a hope of curing the disease, in addition to living with the virus, demystifying the idea of a deadly disease. Upon mentioning $\mathrm{HIV}$ as a chronic disease which requires care, the naturalization of the process of living with HIV is favored.

This study is expected to generate critical and humanized reflections among all health professionals involved in providing care to these pregnant women, so as to improve, before anything, reception and care, since these women require support to face reality with the conflicts related to living with HIV. 
RESUMO

Objetivo: Identificar os conteúdos representacionais de gestantes vivendo com o HIV. Método: Pesquisa exploratória, descritiva, com abordagem qualitativa, realizada com gestantes com HIV entre agosto de 2017 e janeiro de 2018. Optou-se por entrevista semiestruturada. Para a análise se utilizou o software IRAMUTEQ, organizando os dados em 2 blocos: a) momento da descoberta, impactos e conteúdos representacionais do HIV; e b) conteúdos representacionais no viver com a doença. Resultados: Participaram 25 gestantes. Inicialmente, observou-se que a representação social do HIV traduz a representação da morte; porém, essa construção se altera à medida que as mulheres compreendem as informações sobre a patologia e esta passa a ser vista como uma doença que requer maiores cuidados. Conclusão: Ainda se concebe o HIV como algo digno de temor, principalmente devido ao receio de transmiti-lo ao feto. Constatou-se a ressignificação do HIV entre as gestantes, algo que favorece novos comportamentos e atitudes diante de conteúdos representacionais relativos ao conhecimento mais aprofundado sobre o vírus e desmistifica a ideia de que se trata de uma doença mortal.

\section{DESCRITORES}

Gestantes; HIV; Síndrome de Imunodeficiência Adquirida; Percepção Social; Enfermagem Obstétrica.

\section{RESUMEN}

Objetivo: Identificar los contenidos representacionales de mujeres embarazadas que viven con el VIH. Método: Investigación exploratoria, descriptiva y cualitativa realizada con mujeres embarazadas con VIH entre agosto de 2017 y enero de 2018 . Se optó por entrevistas semiestructuradas. Para el análisis, se utilizó el software IRAMUTEQ, organizando los datos en dos bloques: a) momento del descubrimiento, impactos y contenidos representacionales del VIH; y b) contenidos representacionales de la convivencia con la enfermedad. Resultados: Participaron 25 mujeres embarazadas. Inicialmente, se observó que la representación social del VIH traduce la representación de la muerte; sin embargo, la construcción cambia a medida que las mujeres comprenden la información sobre la patología, que comienza a ser vista como una enfermedad que requiere mayores cuidados. Conclusión: El VIH aún se concibe como algo digno de miedo, principalmente debido al temor de transmitirlo al feto. Se constata la resignificación del VIH entre las mujeres embarazadas, algo que favorece nuevos comportamientos y actitudes a partir de contenidos representacionales relativos al conocimiento más profundo sobre el virus y desmitifica la idea de que se trata de una enfermedad mortal.

\section{DESCRIPTORES}

Mujeres Embarazadas; VIH; Síndrome da Inmunodeficiencia Adquirida; Percepción Social; Enfermería Obstétrica.

\section{REFERENCES}

1. Ayala ALM, Moreira A, Francelino G. Características socioeconômicas e fatores associados à positividade para o HIV em gestantes de uma cidade do Sul do Brasil. Rev APS [Internet]. 2016 [cited 2021 fev. 19];19(2):210-20. Available from: https://periodicos.ufjf.br/index. php/aps/article/view/15666

2. Mombelli MA, Barreto MS, Arruda GO, Marcon SS. AIDS epidemic in the triple frontier: subsidies for professional practice. Rev Bras Enferm. 2015;68(3):429-37. https://doi.org/10.1590/0034-7167.2015680308i

3. Boletim Epidemiológico de HIV e AIDS. Brasília: Ministério da Saúde; Secretaria de Vigilância em Saúde [Internet]. 2019 [cited 2021 fev. 19];(n.esp.). Available from: http://www.aids.gov.br/pt-br/pub/2019/boletim-epidemiologico-de-hivaids-2019

4. Redmond AM, McNamara JF. The road to eliminate mother-to-child HIV transmission. J Pediatr. 2015;91(6):509-11. https://doi. org/10.1016/j.jped.2015.08.004

5. Medeiros APDS, Araújo VSA, Moraes MN, Almeida AS, Almeida JN, Dias MD. Pregnant women's experience of being seropositive for HIV/AIDS: prejudice, pain, trauma and suffering at the discovery. Rev Enferm UERJ. 2015;23(3):362-7. https://doi.org/10.12957/ reuerj.2015.17918

6. Dadhwal V, Sharma A, Khoiwal K, Deka D, Sarkar P, Vanamail P. Pregnancy outcomes in HIV-infected women: experience from a tertiary care center in India. Int J MCH IDS. 2017;6(1):75-81. https://doi.org/10.21106/ijma.196

7. Flament C, Rouquette ML. Anatomie des idées ordinaires. Paris: Armand Colin; 2003.

8. Jodelet D. As representações sociais. Rio de Janeiro: Ed. UERJ; 2001. Representações sociais: um domínio em expansão; p. 17-44.

9. Ferreira MA. Theory of social representations and contributions to the research of health care and nursing. Esc Anna Nery. 2016;20(2):214-9. http://dx.doi.org/10.5935/1414-8145.20160028

10. Moscovici S. Representações sociais: investigações em psicologia social. 11ª ed. Petrópolis: Vozes; 2017.

11. Nemer CRB, Sales BLD, Ranieri BC, Lemos LL, Santos ISR, Pena FPS, et al. HIV e teste rápido: representações sociais. Rev Enferm UFPE On Line. 2019;13:e239280. https://doi.org/10.5205/1981-8963.2019.239280

12. Santos MP. A teoria das representações sociais como referencial didático-metodológico de pesquisa no campo das ciências humanas e sociais aplicadas. Rev Emancip. 2013;13(1):9-21. https://doi.org/10.5212/Emancipacao.v.13i1.0001

13. Braga RMO, Lima TP, Gomes AMT, Oliveira DC, Spindola T, Marques SC. Social representations of HIV/AIDS for people living with the syndrome. Rev Enferm UERJ. 2016;24(2):e15123. http://dx.doi.org/10.12957/reuerj.2016.15123

14. Bezerra EO, Pereira MLD, Maranhão TA, Monteiro PV, Brito GCB, Chaves ACP, et al. Structural analysis of social representations on aids among people living with human immunodeficiency virus. Texto Contexto Enferm. 2018;27(2):e6200015. https://doi.org/10.1590/0104070720180006200015

15. Trigueiro DRSG, Almeida SA, Monroe AA, Costa GPO, Bezerra VP, Nogueira JA. AIDS and jail: social representations of women in freedom deprivation situations. Rev Esc Enferm USP. 2016;50(4):554-61. http://dx.doi.org/10.1590/S0080-623420160000500003 
16. Rael CT, Carballo-Diéguez A, Norton R, Thorley E, Giguere R, Sheinfil A, et al. Identifying strategies to cope with HIV-related stigma in a group of women living with HIV/AIDS in the Dominican Republic: a qualitative study. AIDS Behav. 2017;21(9):2589-99. https://doi. org/10.1007/s10461-016-1654-9

17. Oliveira DC. Construction and transformation of social representations of AIDS and implications for health care. Rev Latino Am Enfermagem. 2013;21(spe):276-86. https://doi.org/10.1590/S0104-11692013000700034

18. Agbo S, Rispel LC. Factors influencing reproductive choices of HIV positive individuals attending primary health care facilities in a South African health district. BMC Public Health. 2017; 17:540. https://doi.org/10.1186/s12889-017-4432-3

19. Bastos RA, Bellini NR, Vieira CM, Campos CJG, Turato ER. Psychological phases of pregnant women with HIV: a qualitative study in a hospital. Rev Bioética. 2019;27(2):281-8. https://doi.org/10.1590/1983-80422019272311

20. Bellotto PCB, Lopez LC, Piccinni CA, Gonçalves TR. Entre a mulher e a salvação do bebê: experiências de parto de mulheres com HIV. Interface (Botucatu). 2019;23:e180556. http://dx.doi.org/10.1590/interface.180556

21. Lôbo ALSF, Santos AAP, Pinto LMTR, Rodrigues STC, Lima MGT, Bastos LJD. Social representations of women who live with the human immunodeficiency virus and want to conceive. Texto Contexto Enferm. 2018;27(3):e4440016. https://doi.org/10.1590/0104 07072018004440016 